\title{
Starch Digestion in Young Children with Cystic Fibrosis Measured Using a ${ }^{13} \mathrm{C}$ Breath Test
}

\author{
ODILE DEWIT, ANN PRENTICE, W. ANDREW COWARD, AND LAWRENCE T. WEAVER
}

Medical Research Council Dunn Nutrition Unit, Cambridge CB4 IXJ, United Kingdom

\begin{abstract}
The study was designed to evaluate a noninvasive breath test using naturally ${ }^{13} \mathrm{C}$-rich corn (maize) as substrate to provide quantitative information about the digestion of starch by children in health and disease. The variability of background ${ }^{13} \mathrm{C}^{\cdot 12} \mathrm{C}$ of young British children was investigated by collecting breath samples over $6 \mathrm{~h}$ from 17 healthy children, 6-35 mo old, and from seven children with cystic fibrosis, 25-48 mo old, in their homes. Background ${ }^{13} \mathrm{C}$ enrichment was -26.6 and $-25.4 \mathrm{\partial}$ per mil in the healthy and cystic fibrosis groups, respectively $(p<0.01)$, and varied little during the day $(\mathrm{SD}=0.4 \mathrm{\partial}$ per mil). Eight healthy children and five with cystic fibrosis were given a test breakfast of corn starch cooked in milk with sugar. The cystic fibrosis group repeated the test with the addition of an enzyme supplement containing $\alpha$-amylase. Subjects accepted variable amounts of starch (range $0.2-2.8 \mathrm{~g} / \mathrm{kg}$ body wt). The percentage of ingested ${ }^{13} \mathrm{C}$ recovered during the $6 \mathrm{~h}$ after the meal increased with age in the healthy children (range 15-53\%). Three children with cystic fibrosis had negligible ${ }^{13} \mathrm{C}$ recoveries, and the other two had lower recoveries than expected for their age. The addition of enzymes did not consistently improve ${ }^{13} \mathrm{C}$ recovery. We conclude that the ${ }^{13} \mathrm{C}$ breath test based on corn has potential for investigating starch digestion in young children. Initial results suggest that starch digestion is impaired in some children with cystic fibrosis and that enzyme supplements do not improve digestion consistently or completely. (Pediatr Res 32: 45-49, 1992)
\end{abstract}

Children with cystic fibrosis have decreased activity of pancreatic amylase (1), the major enzyme involved in the intraluminal hydrolysis of starch. As a consequence, most children with cystic fibrosis receive pancreatic enzyme supplements containing $\alpha$-amylase (2). Although starch is the principal complex carbohydrate in the diet during early life and represents about $20 \%$ of the total energy intake at $2 \mathrm{y}$ of age in children in Europe $(3,4)$, information about the digestion of this carbohydrate in young children with cystic fibrosis is limited (5). In addition, the effect of enzyme supplements on the digestion of starch has not been clearly established in children.

Noninvasive breath tests, which involve substrates that are naturally or artificially labeled with ${ }^{13} \mathrm{C}$, the stable isotope of carbon, have been used to make quantitative measurements of the digestion of complex carbohydrates in healthy infants and adults $(6,7)$ and in those with pancreatic insufficiency $(8)$. When

Received April 19, 1991; accepted February 21; 1992.

Correspondence: Dr. Odile Dewit c/o Dr. Ann Prentice, Medical Research Council Dunn Nutrition Unit, Downham's Lane, Milton Road, Cambridge CB4 $1 \mathrm{XJ}$, England, UK.

Reprint requests: Dr. Ann Prentice, Medical Research Council Dunn Nutrition Unit, Downham's Lane, Milton Road, Cambridge CB4 1XJ, England, UK.

Supported by the Commission of the European Communities (Research Contract Stimulation Action ST2*0447, Brussels, Belgium).
${ }^{13} \mathrm{C}$-rich starch is hydrolyzed into glucose, the ${ }^{13} \mathrm{C}$ in excess above the natural background is transferred to glucose. The subsequent oxidation of glucose leads to $\mathrm{CO}_{2}$ that is enriched with ${ }^{13} \mathrm{C}(9)$, and the measurement of ${ }^{13} \mathrm{CO}_{2}$ in excess above background gives information on the digestion of starch and its subsequent metabolic use. Foods rich in ${ }^{13} \mathrm{C}$ [principally foods containing or made from corn (maize) and cane sugar] (10) are not widely consumed in the United Kingdom, and it was therefore anticipated that background level of ${ }^{13} \mathrm{C}$ in British children would be relatively low, allowing the use of naturally ${ }^{13} \mathrm{C}$-rich corn starch as substrate. The use of naturally labeled substrates for studies of digestion is attractive because of their increased acceptability for pediatric studies, their ready availability, and their low cost compared with highly labeled substrates prepared artificially. However, no detailed information on the variations of background ${ }^{13} \mathrm{C}:{ }^{12} \mathrm{C}$ levels in the United Kingdom is available to assess whether changes in isotopic abundance in breath after the ingestion of corn starch are detectable above background, although preliminary data in young children from Cambridge, UK, have been reported recently (11).

This study was designed to evaluate a ${ }^{13} \mathrm{C}$ breath test with corn starch as substrate for the measurement of starch digestion in young children, both those in health and those with cystic fibrosis, in a domestic rather than a hospital setting and to assess the effects of pancreatic enzyme supplements.

\section{SUBJECTS AND METHODS}

Subjects. Seventeen healthy children were recruited into the study. They were aged 5.9-35.5 mo (median age $20.8 \mathrm{mo} ; 10$ girls, seven boys) with weight for age ranging from 80 to $116 \%$. Eight children were involved in the full study and nine in the investigation of background levels only.

Seven children with cystic fibrosis, aged 25.5-48.4 mo (median age $26.9 \mathrm{mo}$; four girls, three boys), were recruited into the study. The diagnosis of cystic fibrosis in each subject was made by neonatal blood immunoreactive trypsin screening (12) with confirmation by sweat test. At the time of the study, the children were clinically well and free of respiratory infection and showed no evidence of chronic malabsorption or lung disease. All subjects were receiving regular pancreatic enzyme supplementation. Their nutritional status was good, with weight for age ranging from 98 to $107 \%$ of the National Center for Health Statistics median.

The study was designed to take place in the children's homes to minimize alterations to the subjects' everyday lives. The investigations were approved by the Ethical Committee of the Medical Research Council Dunn Nutrition Unit, Cambridge, UK, and informed consent was given by the parents of all children.

Study design. Breath samples were collected after an overnight fast and at 30-min intervals for $6 \mathrm{~h}$ after ingestion of the test meals (see below). Mixed expired air was collected from children under 18 mo using a supple rubber face mask fitted with two nonreturn valves $(6)$. Older children provided end-expiratory air 
using a 'bubble-box' designed and made in the Dunn Nutrition Center (11).

The test meal was given in place of breakfast. It consisted of freshly prepared custard made from corn starch cooked with UK-produced milk. Beet sucrose was added to taste. The final proportions of ingredients for the cooked custard were starch $10 \%$, milk $86 \%$, and sucrose $4 \%$. The natural ${ }^{13} \mathrm{C}:{ }^{12} \mathrm{C}$ ratio in the corn starch was 0.0109901 ( $-11.2 \partial$ per mil), which was substantially higher than those of milk and sucrose used: $0.0108163(-26.9 \partial$ per mil) in milk and $0.0108265(-26.0 \partial$ per mil) in beet sucrose. The ${ }^{13} \mathrm{C}:{ }^{12} \mathrm{C}$ ratio in the test meal was $0.0109127(-18.2 \partial$ per mil). Children were offered a portion of $225 \mathrm{~g}$ of custard and allowed to eat ad libitum. The quantity of custard consumed was determined by weighing the bowl before and after the meal and any spills were taken into account. The amount of corn starch ingested varied widely between the subjects (Table 1). In absolute terms, the average intake was similar between the healthy group and the group of children with cystic fibrosis, but on the basis of $\mathrm{g}$ corn starch $/ \mathrm{kg}$ body wt, the children with cystic fibrosis ate less $(0.65 \mathrm{~g} / \mathrm{kg} ; \mathrm{SD}=0.3 ; n=10)$ than the healthy children $(1.6 \mathrm{~g} / \mathrm{kg} ; \mathrm{SD}=0.9 ; n=8 ; p<0.05)$.

Children with cystic fibrosis were studied twice in random order. On one day, the corn starch test breakfast was supplemented with six to 10 capsules of pancreatic enzyme supplements containing $\alpha$-amylase (2) (Creon; Duphar Laboratories, Southampton, UK), the number of capsules depending on the subject's age. On the other day, the subjects received no enzyme supplement with the test breakfast. No ill effects of omitting the enzyme supplements were noted. Healthy children were studied with the corn starch test breakfast, without enzyme supplements.

Because the tests lasted $6 \mathrm{~h}$, no restrictions were made on activity and drinking and eating, with the proviso that foodstuffs were limited to those in which ${ }^{13} \mathrm{C}$ abundance did not differ significantly from the background value; thus, foods such as those containing corn or cane sugar were to be avoided. The pattern of eating was generally similar between children, and the effect of eating during the day was studied as described below. Children with cystic fibrosis took their pancreatic enzyme sup- plements as usual with any snacks and meals consumed after the test meal.

The effects on basal ${ }^{13} \mathrm{C}$ abundance of the ingestion of constituents other than the corn starch at breakfast (10) and during the day (13), as well as those of the activity $(13,14)$, were assessed on a separate day in the healthy children and in the children with cystic fibrosis when taking enzyme supplements and also when not taking them. The experimental design was similar to the study days, with the breakfast consisting of starch, milk, and beet sugar as did the test breakfasts, the only difference being that the starch was from rice, which has a low ${ }^{13} \mathrm{C}$ abundance $(10,13,14)$. The ${ }^{13} \mathrm{C}$ content of this blank breakfast was -26.3 $\partial$ per mil.

Compliance of subjects. The breath tests were well accepted by all the infants and their mothers and all study days were completed. However, on some occasions, it was discovered retrospectively that children had unknowingly taken ${ }^{13} \mathrm{C}$-rich foods, which invalidated the tests. In the group of healthy children, valid data were available as follows: corn starch tests in eight subjects; rice starch tests in seven; and information on ${ }^{13} \mathrm{C}$ baseline in fifteen. In the group of children with cystic fibrosis, valid data were available as follows: corn starch tests with and without enzymes in five subjects; nine rice starch tests comprising eight tests with and without enzymes in four subjects and one test with enzymes only in one subject; and information on ${ }^{13} \mathrm{C}$ baseline in five subjects.

Measurement of ${ }^{13} \mathrm{C}$ enrichment in breath and in foods. The ratio of ${ }^{13} \mathrm{C}$ to ${ }^{12} \mathrm{C}$ was measured in expired $\mathrm{CO}_{2}$ using an automated isotope ratio mass spectrometer (Sira-10; VG-Isogas, Manchester, UK). For foodstuffs, the ratio was determined in the $\mathrm{CO}_{2}$ obtained from combustion of the sample. The ${ }^{13} \mathrm{C}$ abundance was calculated as relative differences, or $\partial$ values, with respect to the international limestone standard (Peedee Belemnite, PDB), after correction for the abundance of oxygen isotopes (15). The $\partial$ values, expressed per mil, were given by: $\partial^{13} \mathrm{C}=\left[\left(\mathrm{R}_{\mathrm{x}} / \mathrm{R}_{\mathrm{PDB}}\right)-1\right] \cdot 10^{3}$, where $\mathrm{R}_{\mathrm{x}}={ }^{13} \mathrm{C}:{ }^{12} \mathrm{C}$ in the sample and $\mathrm{R}_{\mathrm{PDB}}={ }^{13} \mathrm{C}:{ }^{12} \mathrm{C}$ in $\mathrm{PDB}=0.0112372$ (15). The precision $(\mathrm{SD})$ of the ratio measurements was $0.011 \partial$ per mil. The inter-

Table 1. Amounts of corn starch ingested in test meal, quantities of amylase in enzyme supplements received with test meal, and breath ${ }^{13} C$ recovery in healthy children $(C)$ and in children with cystic fibrosis $(F)$

\begin{tabular}{|c|c|c|c|c|c|c|}
\hline \multirow[b]{2}{*}{ Subject } & \multirow[b]{2}{*}{$\begin{array}{l}\text { Age } \\
(\mathrm{mo})\end{array}$} & \multicolumn{2}{|c|}{$\begin{array}{c}\text { Quantity starch } \\
\text { eaten }\end{array}$} & \multirow[b]{2}{*}{$\begin{array}{l}\text { Amylase supplements } \\
\text { (BP units)* }\end{array}$} & \multicolumn{2}{|c|}{$\begin{array}{l}\text { 6-h cumulative } \% \text { dose } \\
\text { recovery }\end{array}$} \\
\hline & & $\mathrm{g}$ & $\mathrm{g} / \mathrm{kg}$ & & $\begin{array}{l}\text { Threshold } \dagger \\
(\%)\end{array}$ & $\begin{array}{c}\text { Observed } \\
(\%)\end{array}$ \\
\hline $\mathrm{C} 11$ & 5.9 & 9.0 & 1.3 & & 5 & 15 \\
\hline $\mathrm{C} 16$ & 8.4 & 14.4 & 1.6 & & 4 & 17 \\
\hline $\mathrm{C} 12$ & 8.6 & 27.9 & 2.8 & & 2 & 18 \\
\hline $\mathrm{C} 10$ & 8.9 & 13.5 & 2.0 & & 3 & 13 \\
\hline $\mathrm{C} 06$ & 11.2 & 4.5 & 0.5 & & 14 & 39 \\
\hline $\mathrm{C} 14$ & 20.8 & 3.4 & 0.3 & & 23 & 53 \\
\hline F01 & 25.5 & 3.3 & 0.3 & & 23 & 32 \\
\hline $\mathrm{F} 01 /+\ddagger$ & & 8.1 & 0.7 & 46200 & 10 & b.t. $\S$ \\
\hline F03 & 26.3 & 7.4 & 0.6 & & 11 & b.t. \\
\hline $\mathrm{F} 03 /+$ & & 7.5 & 0.6 & 57000 & 11 & 22 \\
\hline F02 & 48.4 & 18 & 1.1 & & 6 & 33 \\
\hline $\mathrm{F} 02 /+$ & & 12.8 & 0.8 & 95000 & 9 & 34 \\
\hline
\end{tabular}

* BP, British Pharmacopoeia method of analysis (2).

$\uparrow$ Minimum significant 6 -h cumulative $\%$ dose recovery for the dose eaten by the child.

$\ddagger$ The sign $/+$ indicates that the test meal was supplemented with enzymes.

$\S$ b.t., observed value below threshold. 
assay measurement error, which includes errors from collection, preparation, and measurement, determined on 311 pairs of duplicated samples, was $0.141 \partial$ per mil (SD of the differences/ $\sqrt{ } 2)$.

Baseline breath ${ }^{13} \mathrm{C}$ abundance for each individual was taken as $\partial^{13} \mathrm{C}$ in the breath sample obtained before breakfast after an overnight fast. This value was not significantly different from the average $\partial^{13} \mathrm{C}$ obtained over $6 \mathrm{~h}$ after breakfast in the absence of corn starch $(p=0.5)$. On nine of the test days, $\partial^{13} \mathrm{C}$ values before breakfast were particularly high (Fig. 1 , stars). It was discovered later by questioning the mothers that these subjects either had not fasted overnight or their diet on the day before the test had been rich in ${ }^{13} \mathrm{C}$. The measurements on these study days were rejected and not included in further analysis. Any change in ${ }^{13} \mathrm{C}$ abundance greater than $0.8 \partial$ per mil was regarded as significant. This minimum detectable change in ${ }^{13} \mathrm{C}$ abundance represents twice the $\mathrm{SD}$ of ${ }^{13} \mathrm{C}$ background variations during the day averaged over all healthy subjects (see Results). The time of appearance of ${ }^{13} \mathrm{C}$ in breath was defined as the time at which the ${ }^{13} \mathrm{C}:{ }^{12} \mathrm{C}$ ratio first rose above this minimum level of detection and was arbitrarily taken as the average time between the last time when ${ }^{13} \mathrm{C}$ abundance was not significantly higher than baseline and the first time when it was.

The digestion of starch was measured as the percentage of the ingested dose of ${ }^{13} \mathrm{C}$ that was recovered in breath for each time interval and cumulated over the 6-h test period. Breath ${ }^{13} \mathrm{C}$ recovery $\left(\mathrm{mmol}{ }^{13} \mathrm{C}\right)$ was calculated from the increase of ${ }^{13} \mathrm{C}:{ }^{12} \mathrm{C}$ ratio in excess above baseline ratio versus time, using the trapezoidal rule and a constant value of $5 \mathrm{mmol} \mathrm{CO} 2$ produced per min and per $\mathrm{m}^{2}$ body surface area (16) for all children. This approximate value was used here because of the technical impossibility of measuring $\mathrm{CO}_{2}$ production in free-living infants and toddlers over $6 \mathrm{~h}$ in a domestic setting. This value is customarily used by different authors $(6,17,18)$ in the absence of comprehensive data on $\mathrm{CO}_{2}$ production rates in childhood and infancy in free-living conditions. To evaluate the effect of background fluctuations on measured recoveries, a curve was constructed with a maximum amplitude of $2 \mathrm{SD}$ of the measured background variations $(0.8 \partial$ per mil). The shape of the curve was taken as quadratic, with peak excretion occurring at $3.5 \mathrm{~h}$ and excretion returning to baseline at $6.6 \mathrm{~h}$, determined from the average measured values in the healthy children (see Results). This curve defined a threshold level characteristic of the child and of the dose eaten on that day by that child, a threshold below

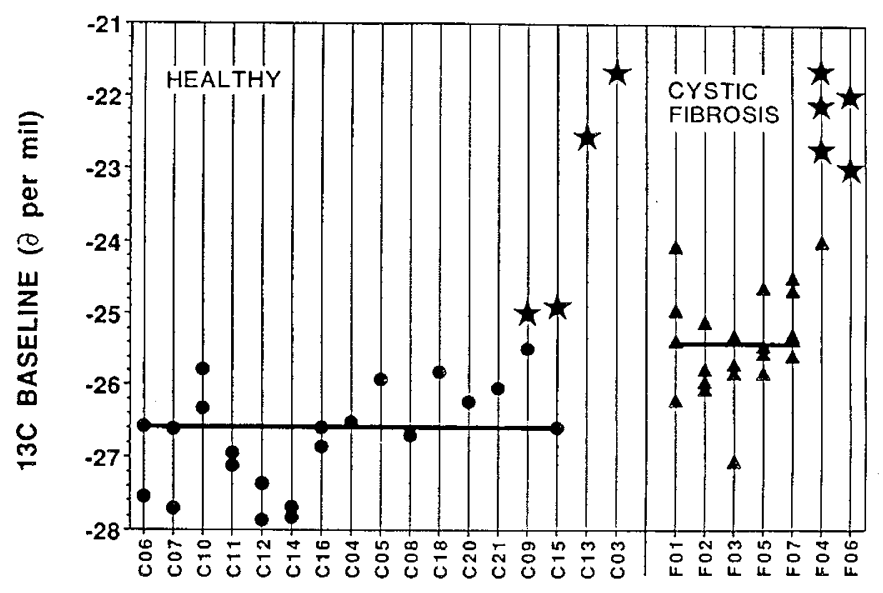

\section{SUBJECTS}

Fig. $1 .{ }^{13} \mathrm{C}$ enrichment $(\partial)$ in the breath sample before breakfast on each test day in all subjects recruited. The circles and triangles represent samples from the healthy subjects and the children with cystic fibrosis, respectively. The stars represent samples when the children were not fasting or when the diet before the test was rich in ${ }^{13} \mathrm{C}$. which recoveries could be ascribed to no more than the background fluctuations.

The statistical analysis was made using nonparametric tests based on the ranking of the observations (Mann-Whitney U test and Wilcoxon's paired T test) (19) and analysis of variance.

\section{RESULTS}

Background breath ${ }^{13} \mathrm{C}$ enrichment. Individual baselines on each study day are presented in Figure 1. On average, the baseline was lower in the healthy group than in the group of children with cystic fibrosis: mean $=-26.6$ versus $-25.4 \partial$ per mil; $\mathrm{SD}=$ 0.7 versus $0.4 ; n=15$ versus $5 ; p<0.01$. The within-child, dayto-day variation of the baseline had an SD of $0.5 \partial$ per mil in the healthy group and $1.0 \partial$ per mil in the children with cystic fibrosis. The variations of ${ }^{13} \mathrm{C}$ basal abundance during the day after ingestion of the blank breakfast were small and not significant: in the healthy group, seven children, 12 breath samples/d/ child, $F_{11,66}=0.9$; and in the group of children with cystic fibrosis, 9 test d, 12 breath samples/d, $F_{11,88}=1.2$. They occurred with an SD of $0.4 \partial$ per mil in the healthy children (range 0.20.8 ) as well as in the children with cystic fibrosis (range $0.1-0.6$ ). The variations in ${ }^{13} \mathrm{C}$ background between individuals were significantly greater than the variations during the day within each subject: in the healthy group, $F_{6,66}=24, p<0.001$; and in the group of children with cystic fibrosis, $F_{8,88}=18, p<0.001$.

Recovery of ${ }^{13} \mathrm{C}$ in breath after test meals. Figure 2 illustrates the individual values of $\partial^{13} \mathrm{C}$ above baseline after ingestion of corn starch, without correction for the dose of starch eaten. In healthy subjects, the rise in ${ }^{13} \mathrm{C}$ abundance was well above $0.8 \partial$ per mil $=2 \mathrm{SD}$ (upper limit of the shaded area) in all cases. The increase in breath ${ }^{13} \mathrm{C}$ abundance was dependent on the amount of starch eaten (healthy group, $n=8, r=0.65$; slope $=0.13 ; p$ $<0.001$ ), and the appearance time was independent of the amount of custard eaten. In children with cystic fibrosis, the magnitude of the increase was less than in healthy children but was greater than the minimum detectable in three children. In two children, no significant increase above baseline was detected: in child F05 (triangles) whether or not enzymes were taken with the test meal and in child F03 (circles) when no enzymes were taken with the test meal.

Figure 3 illustrates the individual ${ }^{13} \mathrm{C}$ recoveries after correction for the ingested doses of starch and cumulated over time. The values are presented in Table 1 . In the healthy subjects, the 6-h cumulative recovery of isotope increased with age $(n=8, \mathrm{~T}$ $=3.7, p<0.01$ ) and ranged from $15 \%$ in child C11, aged 5.9 mo, to $53 \%$ in child $\mathrm{C} 14$, aged $20.8 \mathrm{mo}$. In three children with cystic fibrosis, the recoveries were negligible (F03, circles; F05, triangles; and F07, open squares). In the two others, aged 25.5 and $48.4 \mathrm{mo}$, measurable recoveries ( 32 and $33 \%$ ) were obtained, but in comparison with the healthy children these were lower than might have been expected for their age.

Effects of enzyme supplements (Fig. 3, Table 1). With pancreatic enzymes, ${ }^{13} \mathrm{C}$ recoveries increased by 3 - to 6-fold in child F03 (circles) and child F07 (squares). In child F02 (top plain line), ${ }^{13} \mathrm{C}$ recovery was similar on both occasions. In child F01 (lower plain line), the recovery was below the limit of significance and less than on the day without enzymes. In child F05 (triangles), ${ }^{13} \mathrm{C}$ recovery remained nil.

\section{DISCUSSION}

This investigation provides evidence that the digestion of starch is impaired in some children with cystic fibrosis. The 6-h cumulative recovery of isotope in breath was lower than what might have been expected for their age in two children with cystic fibrosis and was undetectable in three others. Recovery was improved in only two out of five children with cystic fibrosis when they received supplementary pancreatic amylase. These results contrast with previous studies of starch digestion in sub- 

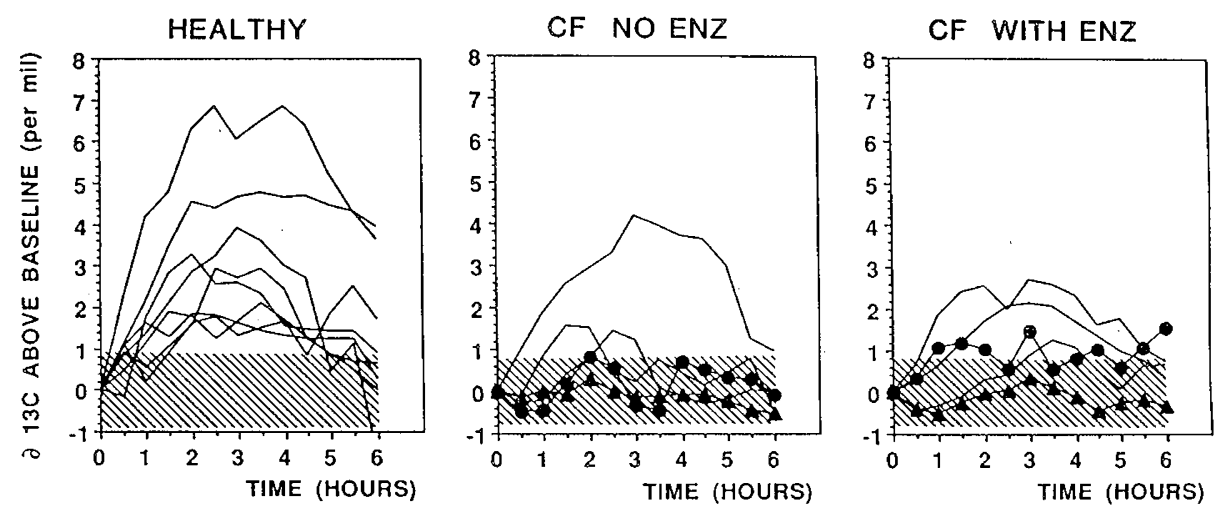

Fig. 2. Individual values of $\partial^{13} \mathrm{C}$ in excess above baseline after ingestion of the test meal (immediately after time 0 ) without correction for the ingested ${ }^{13} \mathrm{C}$ dose in the healthy children and in the children with cystic fibrosis when no enzyme supplements were taken with the test meal $(C F$ NO ENZ) and when enzyme supplements were taken (CF WITH ENZ). Samples from each subject are linked by a continuous line. The samples from child F05 are represented by triangles, and those from child F03 by circles. The shaded area represents $95 \%$ confidence limits for the variations of the $\partial^{13} \mathrm{C}$ background around the baseline during daytime.
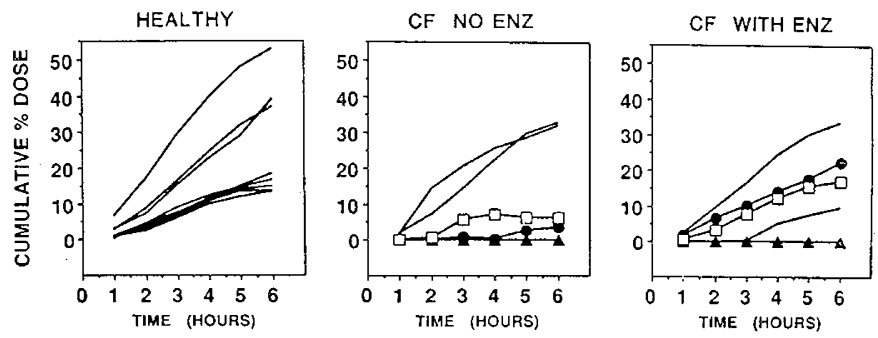

Fig. 3. Individual breath ${ }^{13} \mathrm{C}$ recoveries expressed as cumulative percentage of ingested ${ }^{13} \mathrm{C}$ dose in the healthy children and in the children with cystic fibrosis when no enzyme supplements were taken with the test meal (CF NO ENZ) and when enzyme supplements were taken ( $C F$ WITH ENZ). Samples from each subject are linked by a continuous line. The samples from children F05, F03, and F07 are represented by triangles, circles, and squares, respectively.

jects with cystic fibrosis $(5,20,21)$ using the starch balance technique and the hydrogen breath test, in which the coefficients of absorption of starch obtained were very high (79-99\%). However, those studies measured overall digestion of starch and are not directly comparable to the 6 -h cumulative breath ${ }^{13} \mathrm{C}$ recoveries calculated in the present study. The inconsistent response to enzyme supplementation was unexpected. The enzyme supplements were enteric coated microspheres of pancreatin (2), which were sprinkled on the food either in the spoon or in the bowl immediately before ingestion to avoid enzyme inactivation. The doses received with the test breakfast were above the usual amounts taken. It is interesting to note that there has been a report of a subject with cystic fibrosis in whom absorption of starch was not improved by enzyme supplementation (21).

There are two prerequisites for the use of naturally ${ }^{13} \mathrm{C}$-rich corn starch as substrate in breath tests. First, because the background ${ }^{13} \mathrm{C}:{ }^{12} \mathrm{C}$ ratio marks the level above which ${ }^{13} \mathrm{C}$ abundance increases after ingestion of starch, the ${ }^{13} \mathrm{C}$ background needs to be low in the study area. This was the case in the subjects studied here; the British background levels were much lower than those measured in American infants and children (22). In the children with cystic fibrosis, the ${ }^{13} \mathrm{C}$ background was significantly higher than that in healthy children. This was most likely due to the high-energy drinks based on glucose polymers derived from corn syrup that children with cystic fibrosis often receive. However, the higher basal abundance was not so high that the tests were invalidated. For populations in which the ${ }^{13} \mathrm{C}$ background is higher, the ${ }^{13} \mathrm{CO}_{2}$ signal after ingestion of corn starch may be too weak compared to the ${ }^{13} \mathrm{C}$ variations during the day, and in these circumstances artificially produced substrates with high ${ }^{13} \mathrm{C}$ enrichment would need to be used (23). The second prerequisite is that it is necessary to take into account the variations in basal ${ }^{13} \mathrm{C}$ abundance caused by the ingestion of nutrients other than the substrate and by physical activity $(10,13,14)$. The results of this study showed that in free-living Cambridge children the ${ }^{13} \mathrm{C}$ background varied little during the day ( $S D=0.4 \partial$ per mil). The variations were much smaller than those previously reported in adults (0.51-1.82 $\partial$ per mil) (14) and in two children with cystic fibrosis (SD quoted as less than 0.7 d) (24). This suggests that the strict patterns of rest and feeding used in other studies may not be necessary for digestive studies in young children using a ${ }^{13} \mathrm{C}$ breath test (11). The study, however, emphasized the importance of controlling the intake of ${ }^{13} \mathrm{C}$-rich foods before and during the test.

The study children chose to consume only small amounts of the test meal offered $(0.2-2.8 \mathrm{~g}$ starch $/ \mathrm{kg}$ body wt). However, these amounts were more than adequate to obtain reliable measures of ${ }^{13} \mathrm{C}$ excretion in the breath of these children. It can be calculated that the minimum dose required to obtain a $6-\mathrm{h}$ recovery of $13 \%$, the lowest value observed in the healthy group, is $0.01 \mathrm{~g} \mathrm{starch} / \mathrm{kg}$ body wt. All the children in the study had eaten 20 to 280 times this amount. This is well above the levels chosen as criteria for clinically significant and reliable diagnostic tests (14). In addition, although the amounts of ingested starch varied greatly between children, it is unlikely that any differences in gastric emptying rates substantially modified the pattern of the breath ${ }^{13} \mathrm{C}$ excretion because the time of appearance of increased ${ }^{13} \mathrm{C}:{ }^{12} \mathrm{C}$ ratio in breath was independent of the dose.

Measured differences observed in ${ }^{13} \mathrm{C}$ recoveries between individuals can be ascribed to differences in intraluminal digestion of starch if the absorption and oxidation phases are similar between them. Such assumptions are likely to be reasonable. There has been a report of increased glucose absorption in cystic fibrosis (25), but the implications of this finding in the children of the present study who were of good nutritional status and had no symptoms of mucosal malabsorption are probably not important. The rate of glucose oxidation into $\mathrm{CO}_{2}$ and therefore the rate of $\mathrm{CO}_{2}$ production are likely to be higher in the children with cystic fibrosis who have a raised energy expenditure (26). However, asymptomatic infants with cystic fibrosis have been reported to have normal energy expenditure (27). Although $\mathrm{CO}_{2}$ production rates were not measured individually in this study, the differences in $\mathrm{CO}_{2}$ production rates between the healthy children and those with cystic fibrosis who were asymptomatic would likely be too small to account for the large differences in ${ }^{13} \mathrm{C}$ excretion observed between children.

This study shows that it is possible to detect quantitative differences in intraluminal digestion of starch between healthy young children and those with cystic fibrosis using a noninvasive breath test. The study took place in a domestic setting, and the 
children's cooperation was readily obtained because the study design was not disruptive and was made enjoyable. Our findings emphasize the importance of further research into starch digestion in children with cystic fibrosis, particularly to measure the effectiveness of amylase in pancreatic enzyme supplements. There remains a need for a fuller understanding of the mechanisms of starch digestion in health and disease and the consequences of its impairment.

Acknowledgments. The authors thank the families who took part in the study; Dr. Jan Kuzemko, Dr. Michael Green, and Kathleen Nicholson for their valuable help in recruiting the children with cystic fibrosis; Dr. Dominique Darmaun for helpful criticism; and Duphar Laboratories for their gift of Creon capsules.

\section{REFERENCES}

1. Hadorn B, Zoppi G, Shmerling DH, Prader A, McIntyre I, Anderson CM 1968 Quantitative assessment of exocrine pancreatic function in infants and children. J Pediatr 73:39-50

2. Whitehead AM 1988 Study to compare the enzyme activity, acid resistance and dissolution characteristics of currently available pancreatic enzyme preparations. Pharm Weekbl [Sci] 10:12-16

3. Paul AA, Whitehead RG, Black AE 1990 Energy intakes and growth from two months to three years in initially breast-fed children. J Hum Nutr Diet 3:7992

4. Boggio V, Lestradet H, Astier-Dumas M, Machinot S, Suquet M, Klepping J 1984 Caractéristiques de la ration alimentaire des enfants francais de 3 à 24 mois. Alimentation des nourrissons francais. Arch Fr Pediatr 41:499-505

5. Ciccimara F, DeVizia B, Auricchio S 1970 Il malassorbimento dell'amido nella fibrosi cistica del pancreas. Fracastoro 63:399-403

6. Shulman RJ, Wong WW, Irving CS, Nichols BL, Klein PD 1983 Utilization of dietary cereal by young infants. J Pediatr 103:23-28

7. Hiele M, Ghoos Y, Rutgeerts P, Vantrappen G, de Buyser K $1990{ }^{13} \mathrm{CO}_{2}$ breath test to measure the hydrolysis of various starch formulations in healthy subjects. Gut 31:175-178

8. Hiele M, Ghoos Y, Rutgeerts P, Vantrappen G 1989 Starch digestion in normal subjects and patients with pancreatic disease, using a ${ }^{13} \mathrm{CO}_{2}$ breath test. Gastroenterology 96:503-509

9. Lacroix M, Mosora F, Pontus M, Lefebvre P, Luyckx A, Lopez-Habib G 1973 Glucose naturally labeled with carbon-13: use for metabolic studies in man. Science 181:445-446

10. Schoeller DA, Klein PD, Watkins JB, Heim T, MacLean Jr WC $1980{ }^{13} \mathrm{C}$ abundances of nutrients and the effect of variations in ${ }^{13} \mathrm{C}$ isotopic abun- dances of test meals formulated for ${ }^{13} \mathrm{CO}_{2}$ breath tests. Am J Clin Nutr 33:2375-2385

11. Dewit O, Murgatroyd PR, Prentice A, Coward WA 1990 Background variations in breath carbon- 13 enrichment in free-living infants and toddlers. Proc Nutr Soc 49:5A(abstr)

12. Heeley AF, Heeley ME, King DN, Kuzemko JA, Walsh MP 1982 Screening for cystic fibrosis by dried blood spot trypsin assay. Arch Dis ${ }^{*}$ Child 57:1821

13. Schoeller DA, Brown C, Nakamura K, Nakagawa A, Mazzeo RS, Brooks GA, Budinger TF 1984 Influence of metabolic fuel on the ${ }^{13} \mathrm{C} /{ }^{12} \mathrm{C}$ ratio of breath $\mathrm{CO}_{2}$. Biomed Environ Mass Spectrom 11:557-561

14. Schoeller DA, Schneider JF, Solomons NW, Watkins JB, Klein PD 1977 Clinical diagnosis with the stable isotope ${ }^{13} \mathrm{C}$ in $\mathrm{CO}_{2}$ breath tests: methodology and fundamental considerations. J Lab Clin Med 90:412-421

15. Craig H 1957 Isotopic standards for carbon and oxygen and correction factors for mass-spectrometric analysis of carbon dioxide. Geochim Cosmochim Acta 12:133-149

16. Haycock GB, Schwartz GJ, Wisotsky DH 1978 Geometric method for measuring body surface area: a height-weight formula validated in infants, children, and adults. J Pediatr 93:62-66

17. Lifschitz CH, Boutton TW 1989 A carbon-13 breath test to characterize glucose absorption and utilization in children. [author's reply]. J Pediatr Gastroenterol Nutr 9:541

18. Murray RD, Boutton TW, Klein PD, Gilbert M, Paule CL, MacLean Jr WC 1990 Comparative absorption of $\left[{ }^{13} \mathrm{C}\right]$ glucose and $\left[{ }^{13} \mathrm{C}\right]$ lactose by premature infants. Am J Clin Nutr 51:59-66

19. Schwartz D 1981 Méthodes Statistiques à l'Usage des Médecins et des Biologistes. Flammarion Médecine Sciences, Paris, pp 245-257

20. Hoffman RD, Isenberg JN, Powell GK 1987 Carbohydrate malabsorption is minimal in school-age cystic fibrosis children. Dig Dis Sci 32:1071-1074

21. Perman JA, Rosenstein BJ 1986 Rice starch absorption in cystic fibrosis (CF). Gastroenterology 90:1583(abstr)

22. Boutton TW, Hopkinson JM, Benton DA, Klein PD 1988 Background levels of carbon-13 reduced in breath and stool by new infant formula. J Pediatr Gastroenterol Nutr 7:723-731

23. Boutton TW, Bollich CN, Webb BD, Sekely SL, Nichols BL, Klein PD 1987 ${ }^{13} \mathrm{C}$-labeled rice produced for dietary studies. Am J Clin Nutr 45:844(abstr)

24. Murphy MS, Eastham EJ, Nelson R, Aynsley-Green A 1990 Non-invasive assessment of intraluminal lipolysis using a ${ }^{13} \mathrm{CO}_{2}$ breath test. Arch Dis Child 65:574-578

25. Frase LL, Strickland AD, Kachel GW, Krejs GJ 1985 Enhanced glucose absorption in the jejunum of patients with cystic fibrosis. Gastroenterology $88: 478-484$

26. Shepherd RW, Holt TL, Vasques-Velasquez L, Coward WA, Prentice AM, Lucas A 1988 Increased energy expenditure in young children with cystic fibrosis. Lancet 1:1300-1303

27. Bronstein MN, Accurso FJ, Davies PSW, Hambridge KM 1991 Assessment of total energy expenditure in cystic fibrosis infants identified through newborn screening. Pediatr Res 29:4(abstr) 